\title{
Pemetaan Kedalaman Perairan Danau Maninjau Dengan Algoritma Empirical Bathymetry Method Pada Citra Sentinel 2A Wendri Arifin, Febriandi ${ }^{2}$, dan Triyatno ${ }^{3}$
}

\author{
1,2 Program Studi Teknologi Penginderaan Jauh, Universitas Negeri Padang \\ ${ }^{3}$ Pasca Sarjana Ilmu Lingkungan, Universitas Negeri Padang \\ e-mail: wendriarifin970@gmail.com
}

\begin{abstract}
Lake Maninjau is a lake formed by volcanic activity. Many buman activities occur on the catchment area, but also in exploited waters. This study aims to mapping the depth of the waters in the Lake Maninjau and assess the effect of field sample distribution on the quality results of the image transformation. The data used are satellite imagery Sentinel $2 A$, results of point survey. The analysis technique uses the normalized difference water index algorithm, sun glint, empirical bathymetry method and linear regression. The result of the research which is has found that variations of distribution into the dispersion of the recording process of the depth of the object represented by cell. The depth of the water from the results of this transformation refers to the measurement sample in the field survey. The maximum depth of the waters is in the range of $107 \mathrm{~m}$. Shallow waters are predominantly distributed in the northern region which is the out late of Lake Maninjau. The southern area forms a deep basin. The distribution of this sample is in the form of an empirical bathymetry map and the relationship between the results of field measurements and the transformation with a regression value of 0.769 , this indicates the consideration of total and distribution of survey sample is influence on quality of the results of the transformation.
\end{abstract}

Key words: bathymetry, lake water, image analysis

\begin{abstract}
Abstrak. Danau Maninjau merupakan danau vulkanik dengan kondisi air berupa air tawar. Penelitian ini bertujuan untuk memetakan kedalaman perairan pada kawasan Danau Maninjau Kabupaten Agam dan menilai pengaruh dari distribusi sampel lapangan pada kualitas hasil transoformasi citra. Data yang digunakan citra satelit Sentinel 2A, titik hasil pengukuran lapangan. Teknik analisis menggunakan algoritma Normalized difference water index, sun glint, Emperical Batimetri Methode dan regresi linear. Hasil dari penelitian ditemukan variasi distribusi kedalam peraian dari proses perekaman kedalaman objek yang direpresentasikan oleh piksel citra, yang mana kedalaman perairan dari hasil transofmrasi ini mengacu pada sampel pengukuran di lapangan. Kedalaman maksimum perairan danau berada pada rentang $107 \mathrm{~m}$. Perairan dangkal lebih dominan terdistribusi diwilayah utara perarian yang merupakan outlate dari Danau Maninjau. Sedangkan diwlayah selatan membentuk cekungan dalam. Distribusi sampel ini berupa peta empirical batimetri serta hubungan antara hasil pengukuran lapangan dengan transformasi dengan nilai regresi 0.769 , ini menujukan sampel lapangan memberikan pengaruh yang cukup besar pada hasil transofrmasi.
\end{abstract}

Kata kunci : batimetri, perairan danau, analisis citra

\section{PENDAHULUAN}

Danau merupakan salah satu bentuk daratan alami yang terbentuk melalui proses alam dan memiliki fungsi dan sistem yang sangat kompleks. Ekosistem danau di Indonesia menyimpan kekayaan plasma nutfah, disuplai oleh air permukaan dan dimanfaatkan sepenuhnya untuk pertanian, pengembangan masyarakat, sumber air, perikanan, pertanian, pembangkit listrik tenaga air, pariwisata, dan lain-lain. Saat ini banyak danau di Indonesia telah mengalami degradasi yang disebabkan oleh pertumbuhan penduduk, konversi lahan, limbah, pencemaran bahan kimia dan erosi. Danau Maninjau adalah danau yang berada di Kabupaten Agam, Provinsi Sumatera Barat, Indonesia. Danau Maninjau adalah danau vulkanik yang berada di ketinggian 461,50 mdpl. Ini adalah kaldera dari letusan gunung berapi besar yang menghamburkan material piroklastik sekitar 220-250 km3. Fakta lain juga mengungkapkan bahwa kualitas air Danau Maninjau cenderung menurun dalam dua dekade, akibat meningkatnya pencemaran akibat pembuangan limbah rumah tangga dan pertanian [1]. Dinamika lingkungan yang terjadi di daerah tangkapan air Danau Maninjau adalah degradasi vegetasi yang besar menurunkan kerapatan vegetasi sebagai dampak 
dari perubahan tata guna lahan di sekitar daerah tangkapan [2]. Danau Maninjau dieksploitasi yang tidak diikuti dengan upaya konservasi. Masalah umum yang dihadapi adalah peningkatan kandungan limbah yang mengakibatkan pencemaran dan pendangkalan dari permasalahan tersebut yang pada akhirnya mengakibatkan degradasi lingkungan danau dan matinya ikan di tambak [3].

Pemetaan badan air dan pengukuran batimetri dilakukan dengan cara menurunkan tali atau kabel menggunakan pemberat ke dasar laut. Cara ini kurang efisien karena hanya mengukur kedalaman satu titik dalam waktu yang lama dan memiliki akurasi yang kurang memuaskan. Teknologi mutakhir penginderaan jauh telah banyak digunakan untuk kajian-kajian yang bertemakan limnologi seperti pemantauan kualitas air, pemetaan potensi sumberdaya, dll. Teknologi pengukuran dan pemetaan batimetri selalu berkembang. [4][5]. Selain itu, banyak algoritma penginderaan jauh telah dikembangkan sesuai dengan kebutuhan pengguna dan mengembangkan pemodelan geospasial untuk menilai fenomena lingkungan [6][7]. Teknologi penggunaan sensor aktif (LIDAR) sangat berguna dalam pengamatan lingkungan, teknologi ini mampu membedakan kondisi objek pada informasi titik x, y dan data ketinggian berupa titik z. [8] Namun demikian, dalam teknologi ini juga memberikan kepekaan untuk pengamatan air dengan metode pengukuran batimetri [9]. Metode akustik seperti penggunaan echo-sounder dan multibeam memberikan hasil yang akurat, namun keduanya membutuhkan biaya yang relatif tinggi. wilayah cakupan yang luas dan terbatas. Salah satu solusi untuk mengukur dan memetakan batimetri dengan biaya yang terjangkau dan mencakup wilayah yang luas adalah dengan menggunakan teknologi satelit penginderaan jauh [10] [11]. Saat ini penggunaan kamera digital berbiaya rendah digunakan penuh untuk menangkap dan mengamati citra badan air [12] Maju citra resolusi tinggi seperti Quick-Bird digunakan penuh untuk penyelidikan dan studi tentang proses hidrologi, dinamika air, perubahan sungai dan pengendapan [13]. QuickBird juga digunakan untuk memetakan batimetri dengan spasial $(\sim 2 \mathrm{~m})$ seperti QuickBird dan WorldView-2 dapat menghasilkan peta batimetri yang baik dengan koefisien determinasi di atas 0,80 dan nilai root mean square error (RMSE) di bawah 0,6 m [14]. Sayangnya citra satelit ini mahal harganya. Sebaliknya, penggunaan citra satelit dengan resolusi spasial sedang seperti Landsat $(30 \mathrm{~m})$ secara gratis dapat digunakan untuk menghasilkan peta batimetri resolusi sedang dengan koefisien determinasi 0,6 [14] [15]. Namun demikian, kemajuan penginderaan jauh dalam proyek Copernicus seperti citra sentinel 2a dan kedatangan teknologi baru untuk pemetaan batimetri.

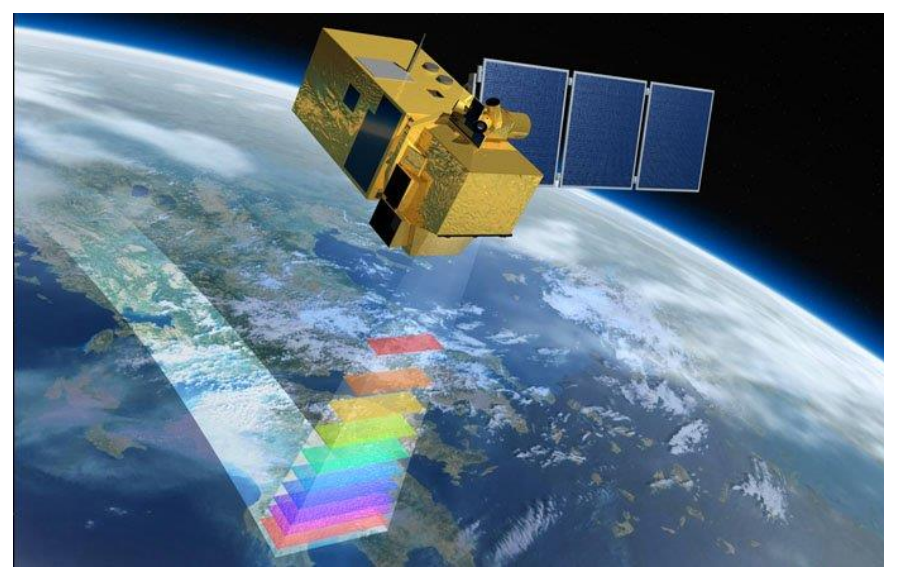

Figure 1. Satellite Sentinel 2 https://eos.com/sentinel-2/

Sentinel-2 adalah misi pencitraan multi-spektral dengan cakupan luas, resolusi tinggi, mendukung studi Pemantauan Lahan Copernicus, termasuk pemantauan vegetasi, tutupan tanah dan air, serta pengamatan jalur air pedalaman dan wilayah pesisir. Instrumen Multispektral SENTINEL-2 (MSI) mengambil sampel 13 pita spektral: empat pita pada 10 meter, enam pita pada 20 meter dan tiga pita pada resolusi spasial 60 meter. Data yang diperoleh, cakupan misi, dan frekuensi kunjungan kembali yang tinggi menyediakan informasi geo pada skala lokal, regional, nasional dan internasional. Data dirancang untuk dimodifikasi dan diadaptasi oleh pengguna yang tertarik pada area tematik seperti: perencanaan tata ruang, pemantauan agro-lingkungan, 
pemantauan hutan dan vegetasi, karbon lahan, pemantauan sumber daya alam, pemantauan tanaman global dan pemantauan air [14][16]. Teknologi sistem informasi geografis yang dikolaborasikan dengan analisis data penginderaan jauh sangat bermanfaat bagi para peneliti dan masyarakat untuk mengamati dan melakukan monitoring lingkungan [17]. Dengan tersedianya data satelit sentinel dengan resolusi yang lebih tinggi dari citra resolusi menengah untuk pengamatan bumi, satelit sentinel dapat digunakan untuk eksplorasi sumber daya air karena didukung oleh sensitivitas spektral untuk objek air. Penelitian ini bertujuan untuk memetakan kedalaman perairan di kawasan Danau Maninjau Kabupaten Agam dan mengkaji pengaruh sebaran sampel lapangan terhadap kualitas hasil transformasi citra. Lokasi penelitian adalah Danau Maninjau, Provinsi Sumatera Barat. Danau ini merupakan danau vulkanik atau biasa disebut kaldera Gunung Tinau yang merupakan hasil letusan gunung purba. Kami memutuskan memilih lokasi ini karena memiliki lanskap geologi dan alam yang unik, serta memiliki permasalahan lingkungan yang kompleks.

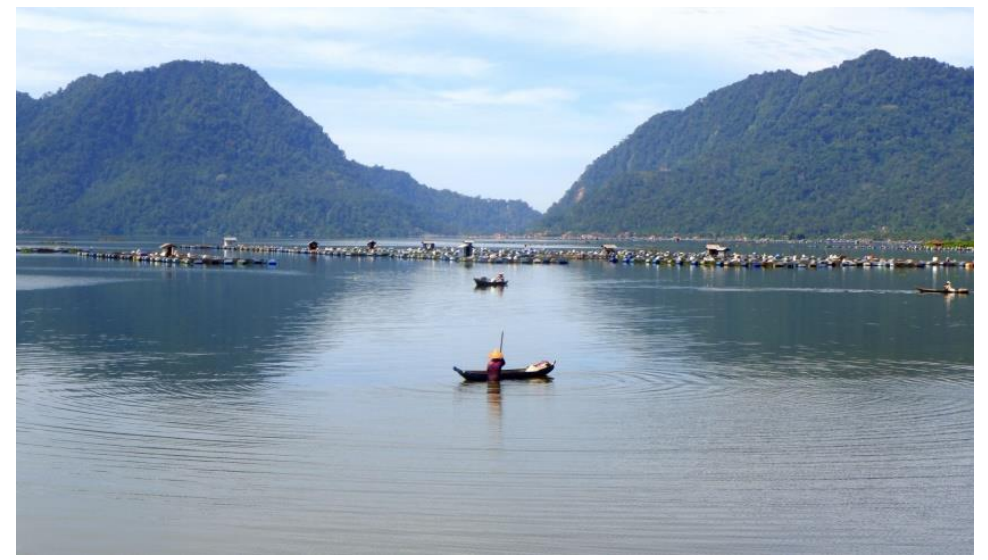

Gambar 2. Kenampakan Danau Manijau, Kabupaten Agam Sumara Barat

\section{METODE}

\subsection{Data}

Dalam penelitian ini kami menggunakan dua data yang kami peroleh dari website dan menanyakan kepada pemerintah. Data yang digunakan adalah citra satelit sentinel 2A yang bersumber dari http://earthexplorere.usgs.gov detail perekaman yaitu 2017-07-23T03:25:41, data satelit ini dapat di akses gratis. Sampel lapangan eco-sounder Echosounder Multibeam, atau Multi Tranducer. yang diperoleh dari River Basin Institute pemerintah Indonesia (BWS V).

\subsection{Analisis}

\section{- Normalized Difference Water Index}

Indeks pemisahan badan air dan daratan digunakan untuk memfokuskan lokasi penelitian pada wilayah perairan, dengan menerapkan algoritma NDWI dapat membedakan antara perairan dan daratan, dimana band / gelombang citra yang digunakan berwarna hijau, swir, persamaan [18] persamaan:

\section{- Sun Glint Correction}

Kilau matahari juga biasa dikenal dengan sebutan Glinting, dimana sun glen adalah kilauan di permukaan air akibat pantulan gemerlap sinar matahari, kondisi gemerlap matahari di permukaan air dapat menyebabkan kesalahan saat memetakan kedalaman. dari badan air, maka persamaan diterapkan [19] persamaan:

$$
\mathrm{R}_{i}^{\prime}=\mathrm{R}_{i}-b i\left(\mathrm{R}_{\mathrm{NIR}}-\min _{\mathrm{NIR}}\right)
$$

\section{- Ratio Transform Algorithm (RTA)}

Salah satu algoritma yang bekerja pada metode batimetri empiris adalah algoritma transformasi rasio, dimana transformasi ini membangun hasil persamaan regresi dari data pengukuran lapangan dengan rasio logaritmik kedua saluran. Citra yang digunakan biasanya berupa pita biru atau pita pantai, algoritma ini mampu mengekstraknya menjadi suatu badan perairan hingga kedalaman 25m, dengan syarat air dalam kondisi tersebut. Metode ini merupakan bagian 
dari metode Batimetri Empiris yang merupakan kunci dalam penelitian ini menggunakan data pengukuran lapangan, dalam penelitian ini untuk data referensi validasi lapangan digunakan data pengukuran dengan hasil pengukuran eco-sounder dengan persamaan BWS River Basin Institute [20]:

$$
\mathrm{Z}=m 1 \frac{\ln (n R w(\lambda i))}{\ln (n R w(\lambda j))}-m 0
$$

Dimana:

$\mathrm{Z}=$ Kedalaman,

m1: adalah (gain) kepada setiap rasio kedalaman,

$\mathrm{m} 0:$ adalah(offset)

rw : reflectan air pada band $K \mathrm{i}$ or $K \mathrm{j}$

$K$ : spectral band

$\mathrm{n}$ : adalah nilai constant setapi area untuk kepercayaan dari nilai logaritma yang positive dari setiap kasus dan rasio yang akan mengacu pada respon regresi linear respon kedalaman air.

\section{HASIL DAN PEMBAHASAN}

Pada proses pemetaan batimetri dengan metode algoritma batimetri empiris akan melalui tiga tahapan pengolahan data utama, dimana digunakan citra sentinel 2a dan secara spesifik adalah pita 2 dan 3. Pemilihan pita 2 dan 3 didasarkan pada spesifikasi sentinel. dan kepekaan gelombang dalam memetakan kedalaman air.

Analisis NDWI tahap pertama dilakukan dimana analisis ini bertujuan untuk memisahkan objek air dan non laut. Pada tahap ini peneliti berhasil mengimplementasikan algoritma NDWI untuk menyorot objek laut dan membedakan objek non perairan untuk dijadikan area fokus dalam proses analisis batimetri, kemudian hasil transformasi citra NDWI dapat dilihat pada peta berikut. Peneliti berhasil melakukan delineasi perairan dengan luas 9.950 ha. Selanjutnya, proses pemetaan batimetri melalui tahap koreksi kilatan matahari. Pada prinsipnya koreksi kilatan matahari bertujuan untuk menghilangkan bias pantulan sinar matahari yang dipantulkan oleh permukaan air ke atmosfir sehingga citra asli akan memperlihatkan kilauan permukaan air sehingga akan menimbulkan kesalahan dalam analisa. Sehingga dengan penerapan koreksi kilatan matahari, kilauan permukaan air dapat diredam sehingga mampu menampilkan tampilan kedalaman air yang sebenarnya sesuai dengan pantulan normal. Pada tahap ini, koreksi kilatan matahari diterapkan pada kedua pita yang digunakan. Berikut ini adalah gambar koreksi kilauan matahari.
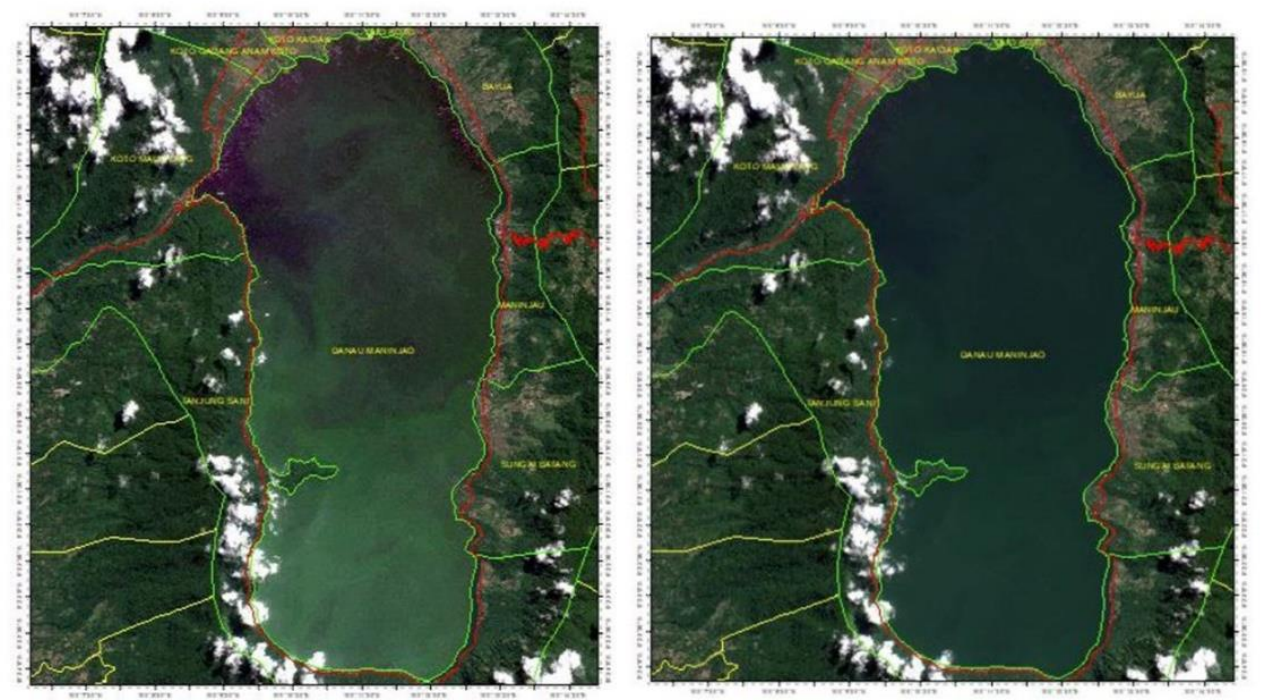

Gambar 3. Perbandingan (a) sebelum koreksi sun glint dan (b) sesudah koreksi sun glint 
Gambar 3 menunjukkan komposit warna sebenarnya dari citra satelit sentinel yang ditransformasikan oleh kilatan matahari. Jumlah digital citra sentinel hasil kilauan matahari berada pada nilai tinggi 4935 dan terendah 0. Dari penampakan citra hasil koreksi kilauan matahari, bias silau matahari tidak terlihat oleh matahari. Perbandingan penampakan gambar sebelum koreksi kilatan matahari dan setelah koreksi, yang hasil kilatan matahari sangat jelas perbedaan penampakan permukaan air. Citra yang dikoreksi oleh sung lint yang bebas dari pantulan cahaya oleh permukaan air cocok untuk proses pendugaan kedalaman air, karena kualitas hasil rekaman bias oleh satelit telah dihilangkan dalam proses ini.

Tahapan selanjutnya adalah analisis batimetri empiris dimana citra yang diolah merupakan keluaran dari koreksi kilatan matahari. Kemudian yang penting dalam proses tersebut adalah transformasi metode batimetri empiris yaitu penggunaan data lapangan sebagai acuan transformasi dalam menganalisis piksel citra. Dalam penelitian ini kami menggunakan data dari survei lapangan dengan menggunakan data eco-sounder yang diperoleh dari Balai Wilayah Sungai (BWS V) sehingga peneliti tidak perlu melakukan pengukuran ulang untuk mengambil data primer. Data survei lapangan yang kami gunakan total sampel adalah 1.220 poin. Titik sampel ini akan menjadi acuan dalam analisis algoritma transformasi rasio, karena dalam ekstraksi piksel citra sentinel menjadi kedalaman perairan, algoritma ini harus memiliki data sampel referensi yang menjadi acuan untuk menghitung perkiraan kedalaman air.

Gambar 3 merupakan hasil data survei batimetri empiris dan interpolasi. Hasil asli batimetri empiris itu menyuguhkan kedalaman. Untuk memudahkan interpretasi kedalaman perairan, maka dilakukan pengelompokan kedalaman dalam bentuk kelas interval. Dari gambar 3 peneliti memberikan lambang biru tua sampai biru cerah, dimana warna biru tua menandakan lokasinya berada di perairan dalam, sedangkan biru cerah merupakan perairan dangkal. Pada penelitian ini juga disajikan hasil interpolasi perairan menggunakan idw untuk membandingkan perairan dari data survei dan hasil transformasi citra satelit. Kedua citra tersebut menunjukkan perbandingan kedalaman perairan terukur di lapangan dengan hasil transformasi citra digital. Informasi peta kurang informatif sehingga perlu dilakukan klasifikasi kedalaman perairan pada skala interval. Berikut gambar peta hasil untuk kedalaman perairan. Dari gambar tersebut terlihat bahwa terdapat perbedaan kedalaman perairan antara hasil interpolasi pengukuran lapangan dengan hasil analisis batimetri menggunakan algoritma citra. Gambar ini membandingkan perbedaan kontras pada obyek perairan dangkal pada kedalaman 0 - 37 meter, dimana pada hasil survey daerah sekitar tepi danau menunjukkan warna pudar yang merupakan kenampakan air dangkal, namun demikian hasil analisa Gambar sentinel 2A, terlihat bahwa perairan dangkal seluas 0 - 37 meter hanya tersebar jelas di kiri kanan danau. Pada model interpolasi perairan dalam 91 107 meter berpusat pada spot di tengah kaldera danau, sedangkan pada model analisis sentinel 2A perairan dalam danau Maninjau lebih banyak tersebar di bagian kaldera danau. . Perbedaan antara hasil pengukuran lapangan dengan hasil analisis citra sentinel disebabkan oleh proses pengumpulan data. Satelit merekam objek berdasarkan respon cahaya yang dipantulkan oleh objek yang memantulkan kedalaman air, hal ini menunjukkan kedalaman air, dan model analisis sentinel ini sangat bergantung pada data lapangan, karena satelit ini bukan satelit yang menggunakan sensor aktif seperti Lidar.

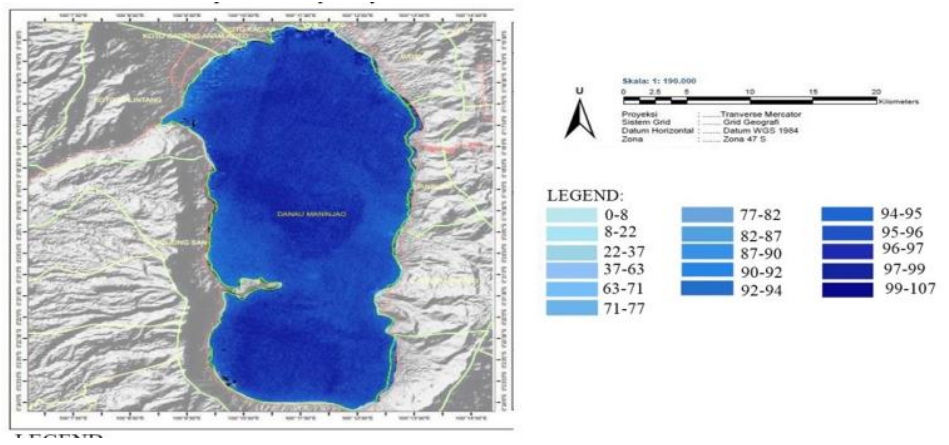

Gambar 4. Peta empirical batymetri hasil analisis Citra Sentinel 
Proses menganalisis hubungan antara data survei dengan hasil transformasi empiris batimetri menjadi penting karena hasil studi pustaka menyatakan bahwa algoritma ini sangat efisien untuk mengukur kedalaman air hingga kedalaman $25 \mathrm{~m}$, sedangkan dari Model transformasi yang dilakukan peneliti berhasil menemukan kedalaman perairan Danau Maninjau dengan kedalaman maksimum $107 \mathrm{~m}$. Hasil penelitian ini sangat relevan dengan konsep transformasi NDWI yang dijelaskan $\mathrm{Xu}$ [18] dimana penggunaan gelombang hijau dan swir pada transformasi NDWI mampu memisahkan objek air dan non-air. Selain itu, hasil penelitian ini juga mengungkap perbandingan informasi citra yang kemunculan objek dari citra hasil koreksi kilatan matahari dan citra asli. Ternyata koreksi kilatan matahari mampu menghilangkan bias cahaya pada air. Informasi citra air sebagai objek penelitian terlihat lebih normal pada citra berwarna sebenarnya. Berdasarkan pernyataan Hedley [19] penerapan koreksi kilatan matahari sangat efektif dalam menghilangkan kilatan cahaya matahari pada permukaan eksposur pada gambar yang direkam. Sehingga temuan dalam hasil penelitian ini sangat relevan dengan pernyataan peneliti sebelumnya mengenai penggunaan metode koreksi kilatan matahari dalam mengurangi bias cahaya di permukaan air.

Kedalaman perairan berhasil dipetakan dalam hal ini dimana diperoleh kedalaman maksimum pada kisaran $107 \mathrm{~m}$, kedalaman sirkulasi ini berasal dari ekstraksi data band 2 dan 3 yang selanjutnya dianalisis dengan data lapangan, distribusi kedalaman. Sirkulasi ini memiliki dua titik utama yang tersebar di wilayah utara. dan selatan. Stumpf [20] yang mengajukan model transformasi empiris batimetri dalam jurnalnya juga berhasil membedakan objek kedalaman air. Sehingga hasil penelitian ini terbukti berhasil mengimplementasikan algoritma yang sama pada lokasi dengan karakteristik geografis yang berbeda.

Uji regresi linier telah berhasil membuktikan performansi antara data lapangan dan hasil transformasi metode batimetri empiris dengan nilai koefisien regresi yang diperoleh yaitu 0,769. Hal tersebut membuktikan bahwa kedua variabel tersebut memiliki hubungan yang kuat. Meskipun demikian kurva regresi linier juga merepresentasikan sejauh mana hubungan kedua variabel dimana variabel $\mathrm{x}$ dan variabel $\mathrm{y}$ tidak terlalu jauh, sehingga dapat dipahami bahwa transformasi empiris metode ini dapat diterapkan di wilayah siaran dengan karakteristik geografis yang berbeda. Data pengukuran lapangan dan objek perairan yang dipetakan dalam kondisi jernih artinya kawasan perairan tidak memiliki suspensi sedimen padat yang menyebabkan kesalahan dalam pemetaan kedalaman air.

\section{KESIMPULAN}

Hasil koreksi sun glint berhasil mengurangi efek pantulan cahaya matahari kepermukaan yang menyebabkan bias cahaya, sehingga kualitas kenampakan dan digital number citra terkoreksi lebih bagus dari pada citra sebelum terkoreksi. Citra terkoreksi ini dianalisis lanjut dengan algoritma batimetri empiris. Distribusi spasial kedelaman perairan tersebar pada wilayah perairan yang menunjukkan adanya variasi kedalaman perairan dari wilayah pinggir danau hingga di tengah dari danau. Klasifikasi data menujukkan yangmana perairan dangkal berada pada interval 0 sampai 8 meter, perairan sedang 77 sampai 92 meter, perairan dalam 93 sampai 96 meter dan perairan sangat dalam 97 hingga 107 meter.

\section{UCAPAN TERIMA KASIH}

Penulis mengucapkan terima kasih kepada pemerintah atas dukungannya dan kami juga mengucapkan terima kasih kepada semua pihak yang telah membantu proses administrasi, serta pihak yang telah membantu kami di lapangan. Terimakasih kepada pembimbing Bapak febriandi dan dukungan dari saudara Muhammad Hanif, untuk kelancaran penelitian ini.

\section{REFERENSI}

[1] Asnil, et al. 2013. Analisis Kebijakan Pemanfaatan Sumberdaya Danau Yang Berkelanjutan (Studi Kasus Danau Maninjau Sumatera Barat). Jurnal Pengelolaan Sumberdaya Alam dan Lingkungan Vol. 3 No. 1 (Juli 2013): 1-9. ISSN 2086-4639. 
[2] Hanif M .2016. Studi Perubahan Kerapatan Vegetasi Catchment Area Danau Maninjau dengan Teknologi Penginderaan Jauh dan Sistem Informasi Geografi.(Skripsi). Padang: FIS UNP.

[3] Lembaga Ilmu Pengetahuan Indonesia. 2010. Kajian Hidroklimatologi Sebagai Dasar Pengembangan Sistem Peringatan Dini Bencana Kematian Massal Ikan 01 Danau Maninjau Sumbar. Laporan Akhir Program Insentif Peneliti Dan Pereka Vasa LIPI.

[4] Wahyuningrum, P.I. 2007. Pengembangan Algoritma untuk Estimasi Kedalaman Perairan Dangkal Menggunakan Data LANDSAT-7 ETM (Studi Kasus Perairan Gugus Pulau Pari Kepulauan Seribu, Jakarta) [Disertasi]. Sekolah Pascasarjana. IPB, Bogor.

[5] Cambell, J. B and R.H. Wynee. 2011. Introduction to Remote Sensing, Fifth Edition. New York: Guildford Press. ISBN 978-1-60918-176-5.

[6] Hidayat R A, dkk. 2020. Spatial Modeling of The Threat of Damage to The Peatland Ecosystem In The Mainland of Bengkalis Regency, Riau Province. Journal Social Polites. Vol 20. Special Issue. No 2. doi: 10.33541/sp.v21i3.2249.

[7] Hanif M, dkk. 2021. Zonation of Conflict between Sun Bear (Helarctos Malayanus) Human as an Effort Wildlife Conflict Mitigation. MAT Journal. Journal of Environmental Engineering and Studies. http://matjournals.in/index.php/JoEES/article/view/6938.

[8] Hanif M and Nofrizal A Y. 2017. Investigation Natural Forest Ecosystem Use High Resolution and Lidar Data. Journal Environment and Earth Science IIESTE. Vol 9.

[9] Halls Joanne and Coastin Kaitlyn. 2016. Submerged and Emergent Land Cover and Bathymetric Mapping of Estuarine Habitats Using WorldView-2 and LiDAR Imagery. Journal Remote Sensing MDPI. Vol 8. Issue 9. DOI. 10.3390/rs8090718.

[10]Arief M. 2012. Pendekatan Baru Pemetaan Bathymetryc Menggunakan Data Jauh SPOT, Studi Kasus Teluk Parigi dan Teluk Popoh. Jurnal Teknologi Dirgantara. 10 (1) : 71-72 Arief M., Hastuti, M., Asriningrum, W., Parwaty, E., Budiman, S.

[11] Horta Joa, etal. 2014. Can recreational Echosounder-Chartplotter systems be used to perform accurate nearshore bathymetric surveys? Journal Ocean Dynamics Springer. 64 (11):1555-1567. DOI: 10.1007/s10236-014-0773-y.

[12] Mokhtar Suhana Ernieza, Mohd Wan Naim Mohd Wan. 2011. Utilizing Low-Cost Digital Cameras And Gis Technique For Mapping Water Quality Of Inland Water Bodies. ISG \& ISPRS 2011, Sept. 27-29,-- Shah Alam, MALAYSIA.

[13] Hanif M. dkk. 2020. The High Resolution Imagery to Mapping the Dynamics of River Flow Patterns, and Deposition on Fluvial Landform of Sianok Canyon. Journal of Remote Sensing GIS and Technology. Volume-6, Issue-1 (January-April. doi.org/10.5281/zenodo.3700308.

[14] Correa Liceaga M. A. -And -Avila Euan J. I. 2002. Assessment of coral reef bathymetric mapping using visible Landsat Thematic Mapper data. International Journal Remote Sensing Vol 23. No 1. 3-14. Taylor and Francis Group. ISSN 0143-1 161. DOI: 10.1080 01431160010008573.

[15] Kiat, Ng Chi. 2004. The kings of the rivers Mahseer in Malayan and the region. Selangor: Inter Sea Fishery.

[16] European Space Agency (2015) Sentinel 2 User Hand Book. Issue 1 Rev 2. European Commission.

[17] Rahman H, dkk. 2020. Spatial Assessment of Landscape Structure Changes and Ecological Connectivity in Padang Pariaman. Journal of Remote Sensing GIS and Technology, 6(2). Available at: https://www.researchgate. net/publication/342707817_Spatial_Assessm ent_of_Landscape_Structure_Changes_and_ Ecological_Connectivity_in_Pariaman. 
[18] Xu, H. 2006. Modofication of Normalized Diffrerence Water Index (NDI) to enchance Open Water Feautures in Remote Sensed Imagery. International Journa of Remote Sensing. Vol 27 (14). Pp. 3025-3033.

[18] Hadley. D., etal. 2005. Technical note. Simple and robust removal of sun glint for mapping shallow water benthos. International Journal of Remote Sensing. Vol 26 (10) pp.2107-2112.

[19] Stumpf. R.P et.al. 2003. Determination of Water Depth With high resolution satellite imagery over variable bottom types. Limnology and Oceanography. Vol 48 (1/2) pp. 547556. 